\title{
Network Single Ion Conductors Based On Comb-Branched Polyepoxide Ethers and Lithium Bis(allylmalonato)borate
}

\author{
Xiao-Guang Sun, John B. Kerr*, Craig L. Reeder, Gao Liu, Yongbong Han \\ Lawrence Berkeley National Laboratory, MS 62-203, \\ One Cyclotron Road, Berkeley, CA 94720 \\ RECEIVED DATE (automatically inserted by publisher); \\ * Corresponding author: jbkerr@lbl.gov
}

\section{Experimental}

\subsection{Materials}

Allyloxy ethanol, 2-[2-chloroethoxy] ethanol, 3-chloro-1-propanol, 3,4-Dihydro-2H-pyran, tetrabutylamonium hydrogen sulfate, triethylene glycol monomethyl ether, hydrochloric acid, diethyl malonate, trimethyl borate, allyl bromide, trichloromethyl silane, 1,2-dichloroethane, 1,1,3,3-tetramethyldisiloxane, sodium metal, lithium ribbon, toluene, benzene, anhydrous methanol, anhydrous ethanol, anhydrous $\mathrm{MgSO}_{4}, \mathrm{NaOH}$ pellet and $\mathrm{KOH}$ pellet were all obtained from Sigma-Aldrich and were used directly without further purification. Tetrahydrafuran (B\&J, distilled in glass) was refluxed over $\mathrm{CaH}_{2}$ for several days before use. Platinumdivinyltetramethyldisiloxane complex in vinylsilicon was obtained from Gelest, Inc.

\subsection{Synthesis}

The synthesis of pentaethylene glycol monomethyl ether, and the intermediate I, Lithium bis \{2- [3-(1, 1, 3, 3 - Tetramethyldisiloxanyl)propyl]malonato $\}$ borate were detailed in reference [1]. The synthesis of epoxide monomers and prepolymers followed the literature procedure with some modifications [2-5], and the following are typical examples of the synthesis. 
2-(2-Chloroethoxy)tetrahydropyran was synthesized from the addition of 2-chloroethanol to 3,4-Dihydro-2H-pyran with hydrochloric acid as catalyst. The crude addition product was dissolved in ether and neutralized with dilute $\mathrm{NaOH}$ aqueous solution, washed with distilled water and dried with anhydrous $\mathrm{MgSO}_{4}$. The solution was filtered and concentrated on a rotary evaporator and distilled with a purity of $99 \%$ by GC analysis. ${ }^{1} \mathrm{H}$ NMR $\left(\mathrm{CDCl}_{3}, \mathrm{ppm}\right): 4.59$ (m, $1 \mathrm{H}), 3.7-4.0(\mathrm{~m}, 2 \mathrm{H}), 3.3-3.7(\mathrm{~m}, 4 \mathrm{H}), 1.2-1.9(\mathrm{~m}, 6 \mathrm{H})$.

2-[2-(2-Allyloxyethoxy)ethoxy]tetrahydropyran 2-allyoxyethanol (350 g, 3.43 moles), 2-(2chloroethoxy)tetrahydropyran (329 g, 2 mole) and tetrabutylammonium hydrogen sulfate (75 g, 0.22 moles) were mixed with $50 \%$ sodium hydroxide aqueous solution $(640 \mathrm{ml})$ and toluene (500ml). The mixture was heated to $70^{\circ} \mathrm{C}$ with mechanical stirring for 16 hours. After cooling to room temperature the mixture was poured into $200 \mathrm{~g}$ crushed ice and mixed well. The upper organic layer was isolated and the aqueous layer was extracted with ether $(100 \mathrm{ml} \mathrm{x} 3)$. The organic layer was then combined and washed with $\mathrm{H}_{2} \mathrm{O}\left(75 \mathrm{ml}\right.$ x 2) and dried over $\mathrm{MgSO}_{4}$. The solution was concentrated on a rotary evaporator. The volatiles were removed under vacuum of 0.2Torr in $130^{\circ} \mathrm{C}$ oil. The residual brownish oil (293g) in the pot was the crude product. Yield: $64 \%, 89.6 \%$ pure by GC analysis. This crude product was directly used for the next step synthesis.

2-(2-Allyloxy-ethoxy)-ethanol 293g crude product of 2-[2-(2Allyloxyethoxy)ethoxy]tetrahydropyran was dissolved in $500 \mathrm{ml}$ ethanol and $20 \mathrm{ml}$ concentrated $\mathrm{HCl}$ in $50 \mathrm{ml}$ distilled water was added. The solution was refluxed overnight, neutralized with $\mathrm{NaHCO}_{3}$ and concentrated under reduced pressure. The residual oil was vacuum distilled and the fraction at $77-79^{\circ} \mathrm{C} / 1.2 \mathrm{~T}$ was collected to get $150 \mathrm{~g}$ product, yield: $81.5 \%, 98 \%$ pure by GC 
analysis. ${ }^{1} \mathrm{H} \mathrm{NMR}\left(\mathrm{CDCl}_{3}\right.$, ppm): $5.88(\mathrm{~m}, 1 \mathrm{H}), 5.26(\mathrm{~d}, 1 \mathrm{H}), 5.17(\mathrm{~d}, 1 \mathrm{H}), 4.01(\mathrm{~d}, 2 \mathrm{H}), 3.5-3.8$ $(\mathrm{m}, 8 \mathrm{H}), 2.52(\mathrm{~s}, 1 \mathrm{H})$.

2-(2-\{2-[2-(2-Methoxyethoxy)ethoxy]ethoxy\}ethoxy)tetrahydropyran Following the same procedure as for 2-[2-(2-Allyloxyethoxy)ethoxy]tetrahydropyran, triethylene glycol monomethyl ether $(260 \mathrm{~g}, 1.59 \mathrm{~mole}), \quad 2-(2-C h l o r o e t h o x y) t e t r a h y d r o p y r a n ~(200 \mathrm{~g}, 1.22 \mathrm{~mole})$ and tetrabutylamonium hydrogen sulfate $(56 \mathrm{~g}, 0.165 \mathrm{~mole}), 50 \%$ sodium hydroxide aqueous solution $(490 \mathrm{ml})$ and toluene $(350 \mathrm{ml})$ were used. After work up, removal of volatiles by rotary evaporation and further purification by distillation under high vacuum of 0.2 Torr in a $130^{\circ} \mathrm{C}$ oil bath, viscous liquid was left, 230g, yield $65 \%, 84 \%$ pure by GC analysis. This crude product was used directly for the next synthesis step.

2-\{2-[2-(2-Methoxyethoxy)ethoxy]ethoxy\}ethanol Following the same procedure used for 2-(2-Allyloxyethoxy)ethanol $\quad 230 \mathrm{~g} \quad 2-(2-\{2-[2-(2-$ Methoxyethoxy)ethoxy]ethoxy\}ehoxy) tetrahydropyran was hydrolysized. After work-up and distillation, the fraction at $102-104^{\circ} \mathrm{C} / 0.4$ Torr was collected to get $128 \mathrm{~g}$ product, yield $78.0 \%$, $97 \%$ pure by GC analysis. ${ }^{1} \mathrm{H}$ NMR $\left(\mathrm{CDCl}_{3}, \mathrm{ppm}\right): 3.4-3.8(\mathrm{~m}, 16 \mathrm{H}), 3.35(\mathrm{~s}, 3 \mathrm{H}), 3.05(\mathrm{~s}, 1 \mathrm{H})$.

2-[2-(2-allyloxyethoxy)ethoxymethyl]oxirane 2-(2-Allyloxyethoxy)ethanol (68g, 0.47mole) was mixed with tetrabutylamonium hydrogen sulfate $(17 \mathrm{~g}, 0.05 \mathrm{~mole}), 50 \%$ sodium hydroxide aqueous solution (190ml). The solution was mechanically stirred and cooled with ice bath to 0$5^{\circ} \mathrm{C}, 250 \mathrm{ml}$ epichlorohydrin was added through a dropping funnel slowly. After addition the reaction was continued for overnight and the solution was poured into $100 \mathrm{~g}$ crushed ice and mixed well. The upper organic layer was isolated and the aqueous layer was extracted with ether (75ml x 3). The organic layer was then combined and washed with $\mathrm{H}_{2} \mathrm{O}(50 \mathrm{ml} \times 2)$ and dried over $\mathrm{MgSO}_{4}$. The solution was concentrated on a rotary evaporator. The residual oil was distilled 
over $\mathrm{CaH}_{2}$ twice and the fraction at $98-100^{\circ} \mathrm{C} / 0.7 \mathrm{~T}$ was collected, $47.5 \mathrm{~g}$, yield: $50 \%, 98.5 \%$ pure by GC analysis. ${ }^{1} \mathrm{H}$ NMR $\left(\mathrm{CDCl}_{3}, \mathrm{ppm}\right): 5.88(\mathrm{~m}, 1 \mathrm{H}), 5.25(\mathrm{~d}, 1 \mathrm{H}), 5.16(\mathrm{~d}, 1 \mathrm{H}), 4.00(\mathrm{~d}, 2 \mathrm{H})$, 3.5-3.9 (m, 9H), 3.41(m, 1H), $3.14(\mathrm{~m}, 1 \mathrm{H}), 2.77(\mathrm{~m}, 1 \mathrm{H}), 2.59(\mathrm{~m}, 1 \mathrm{H})$.

2-(2-\{2-[2-(2-methoxyethoxy)ethoxy]ethoxy\}ethoxymethyl)oxirane Following the same procedure for 2-[2-(2-allyloxyethoxy)ethoxymethyl]oxirane, 2-\{2-[2-(2-Methoxyethoxy)ethoxy] ethoxy \}ethanol $(79 \mathrm{~g}, 0.38 \mathrm{~mole})$, tetrabutylamonium hydrogen sulfate $(13 \mathrm{~g}, 0.038 \mathrm{~mole}), 50 \%$ sodium hydroxide aqueous solution $(130 \mathrm{ml})$ and $200 \mathrm{ml}$ epichlorohydrin was used. After workup and distillation over $\mathrm{CaH}_{2}$ twice and fraction at $136-142^{\circ} \mathrm{C} / 0.1 \mathrm{~T}$ was collected, $60 \mathrm{~g}$, yield: 59\%, $98.0 \%$ pure by GC analysis. ${ }^{1} \mathrm{H} \mathrm{NMR}\left(\mathrm{CDCl}_{3}, \mathrm{ppm}\right): 3.5-3.9(\mathrm{~m}, 17 \mathrm{H}), 3.2-3.5(\mathrm{~m}, 4 \mathrm{H})$, $3.13(\mathrm{~m}, 1 \mathrm{H}), 2.77(\mathrm{~m}, 1 \mathrm{H}), 2.58(\mathrm{~m}, 1 \mathrm{H})$.

Prepolymer NO3 (see Table1) To a well dried 50ml round-bottom flask was charged 2-[2(2-allyloxyethoxy)ethoxymethyl]oxirane $(5.5 \mathrm{~g}, 27.2 \mathrm{mmole})$ and 2-(2-\{2-[2-(2-methoxyethoxy) ethoxy]ethoxy\}ethoxymethyl)oxirane (10g, 37.9mmole) inside a Hellium filled drybox. A magnetic stirrer was added and the flask was sealed with a septum. After taking out of the drybox the solution was degassed first and then flushed with dry Argon. The above process was repeated three times and finally the solution was degassed and heated to $60^{\circ} \mathrm{C} .0 .65 \mathrm{ml} 1 \mathrm{M}$ potassium tert-butoxide solution in THF was injected into the reaction flask through a syringe. The reaction was continued for two days before it was terminated with $1 \mathrm{ml}$ methanol. The cooled solution was dissolved in $50 \mathrm{ml}$ dichloromethane and was extracted with $10 \mathrm{ml}$ de-ioned water. The lower organic layer was separated and solvent was removed on rotary evaporator. The product was further purified by precipitation from ether solution into large amount of hexane twice. The collected prepolymer was dried under high vacuum over $\mathrm{P}_{2} \mathrm{O}_{5}$ for 2 days. $14.0 \mathrm{~g}$ light yellow viscous liquid was obtained, yield, 90\%. $\mathrm{M}_{\mathrm{n}} 1.12 \times 10^{4} \mathrm{~g} / \mathrm{mol}$, PDI $=1.47 .{ }^{1} \mathrm{H}$ NMR 
$\left(\mathrm{CDCl}_{3}, \mathrm{ppm}\right): 5.88(\mathrm{~m}, 1 \mathrm{H}), 5.25(\mathrm{~d}, 1 \mathrm{H}), 5.15(\mathrm{~d}, 1 \mathrm{H}), 3.99(\mathrm{~d}, 2 \mathrm{H}), 3.4-3.8(\mathrm{~m}, 42.4 \mathrm{H}), 3.35(\mathrm{~s}$, $4.2 \mathrm{H})$.

\subsection{Film Casting}

Equal molar amounts of prepolymers and intermediate I (double bond of the allyl group in the prepolymer relative to the $\mathrm{Si}-\mathrm{H}$ group of the intermediate I) were mixed in dry $\mathrm{THF}$ and $\mathrm{Pt}$ catalyst ( 0.5 mole \% relative to the double bond) was added. The homogeneous solution was cast in glass rings on the surface of Teflon plate inside the solvent drybox. The solvent was allowed to evaporate slowly. The formed films were then heated to around $60^{\circ} \mathrm{C}$ for $48 \mathrm{hrs}$ to ensure the reaction as complete as possible. Transparent self-standing films with thickness varying from $50 \mu \mathrm{m}$ to $150 \mu \mathrm{m}$ were obtained. Those membranes were further dried in the antechamber of the drybox with the presence of $\mathrm{P}_{2} \mathrm{O}_{5}$ for two days.

\section{Measurements}

${ }^{1} \mathrm{H}$-and ${ }^{13} \mathrm{C}$-NMR (TMS as internal reference) spectra were collected on a Bruker $300 \mathrm{NMR}$ Spectrometer. GC experiment was performed on 5890 Series II plus Gas Chromatography with SPB5 column (Supelcowax 30 meter, $0.32 \mathrm{~mm}$ I.D., film thickness 0.25 micron) and carrier gas of Helium $(3 \mathrm{ml} / \mathrm{min})$ with a temperature program of $5 \mathrm{~min}$ at $40{ }^{\circ} \mathrm{C}, 10^{\circ} \mathrm{C} / \mathrm{min}$ to $230{ }^{\circ} \mathrm{C}$ and 5 $\min$ at $230^{\circ} \mathrm{C}$.

Glass transition temperatures $\mathrm{T}_{\mathrm{g}}$ were measured using a Perkin Elmer-7 DSC instrument. The heating rate was $10^{\circ} \mathrm{C} / \mathrm{min}$. The molecular weights of the prepolymers were determined by use of an Agilent 1100 series HPLC equipped with a refractive index detector. A PLgel 10um miniMIX-B $250 \times 4.6 \mathrm{~mm}$ column was employed with THF eluent $(0.3 \mathrm{ml} / \mathrm{min})$ and calibrated 
by using polystyrene standard samples in THF with molecular weights ranging from 500 to $3,000,000$.

The measurement of AC conductivity was carried out using a Swagelok cells that have been described before $[6,7]$. A Solartron ${ }^{\mathrm{TM}}$ SI 1254 four-channel frequency response analyzer and a 1286 electrochemical interface were used to measure the impedance of the electrolyte films of known thickness in constant volume cells with blocking electrodes. $\mathrm{Li} / \mathrm{Li}$ cells were constructed inside Helium filled dry box and the cell cycling was carried out at $85^{\circ} \mathrm{C}$ using an Arbin BT 4020 multichannel cycler. The cell cycling sequence unless stated otherwise is $1 \mathrm{hr}$ relaxation, $2 \mathrm{hr}$ charge, $1 \mathrm{hr}$ relaxation and $2 \mathrm{hr}$ discharge.

Postmortem analysis of the polymer membranes was performed by scratching the electrolytes off the electrode and the total weight of the electrolyte was weighed and dissolved in $2.0 \mathrm{ml}$ of de-ioned water. The standard solution was obtained by dissolving $0.1 \mathrm{~g}$ diethylene glycol ethyl ether into $100 \mathrm{ml}$ dichloromethane. $5 \mathrm{ml}$ of such solution was used to extract the above electrolyte solution. The lower dichloromethane solution was separated through a separation funnel and $1 \mathrm{ml}$ was taken to run gas chromatography.

\section{References:}

1. Sun, X.G; Reeder, C.L; Kerr, J.B. Macromolecules, 37(6), 2004, 2219.

2. Kerr, J.B; Sloop, S.E; Liu, G;Han, Y.B; Hou, J; Wang, S. Journal of Power Sources, 2002, $110,389$.

3. Mouzin, G; Cousse, H; Rieu, J.P; Dulfos, A. Synthesis, 1983, 117.

4. Marchese, L; Andrei, M; Roggero, A; Passerini, S; Prosperi, P; Scrosati, B. Electrochimica Acta, 1992, 37(9), 1559. 
5. Nishimoto, A;Agehara, K;Furuya, N; Watanabe, T; Watanabe, M, Macromolecules, 1999, 32,1541 .

6. Doeff, M.M; Edman, L; Sloop, S.E; Kerr, J. B; De Jonghe, L.C. J.Power Sources, 2000, 89, 227.

7. Buriez, O; Han, Y.B; Hou, J; Kerr, J.B; Qiao, J; Sloop, S.E; Tian, M; Wang, S. J. Power Sources, 2000, 89, 149. 
Table 1. Physical properties of prepolymers and single ion conductors

\begin{tabular}{|c|c|c|c|c|c|c|c|c|c|}
\hline \multicolumn{9}{|c|}{ Prepolymers } & \multicolumn{3}{|c|}{ Single ion conductors } \\
\hline NO & Monomer (I) & $\begin{array}{c}\text { Crosslinker } \\
(\mathrm{II})\end{array}$ & $\mathrm{I} / \mathrm{II}$ & $\begin{array}{c}\mathrm{M}_{\mathrm{n}} \\
\times 10^{4}\end{array}$ & $\mathrm{PDI}$ & $\mathrm{T}_{\mathrm{g}} /{ }^{\circ} \mathrm{C}$ & $\mathrm{EO} / \mathrm{Li}$ & $\mathrm{T}_{\mathrm{g}}{ }^{\circ} \mathrm{C}$ & $\begin{array}{c}\text { Log } \sigma_{25} \\
/ \mathrm{S} \mathrm{cm}^{-1}\end{array}$ \\
\hline 1 & $\mathrm{EP}(\mathrm{EO})_{2}$ & AllylE $_{2} \mathrm{Ep}$ & 2.33 & 3.35 & 3.61 & -75.3 & $20: 1$ & -47.2 & -7.56 \\
\hline 2 & $\mathrm{EP}(\mathrm{EO})_{3}$ & AllylE$_{2} \mathrm{Ep}$ & 1.75 & 0.93 & 1.52 & -74.9 & $20: 1$ & -53.0 & -6.90 \\
\hline 3 & $\mathrm{EP}(\mathrm{EO})_{4}$ & AllylE $_{2} \mathrm{Ep}$ & 1.40 & 1.12 & 1.47 & -75.2 & $20: 1$ & -55.3 & -6.35 \\
\hline 4 & $\mathrm{EP}(\mathrm{EO})_{5}$ & AllylE $_{2} \mathrm{Ep}$ & 0.67 & 1.16 & 1.36 & -75.2 & $10: 1$ & -39.4 & -7.51 \\
\hline 5 & $\mathrm{EP}(\mathrm{EO})_{5}$ & AllylE $_{2} \mathrm{Ep}$ & 1.17 & 1.20 & 1.38 & -74.4 & $20: 1$ & -53.1 & -6.14 \\
\hline 6 & $\mathrm{EP}(\mathrm{EO})_{5}$ & AllylE $_{2} \mathrm{Ep}$ & 2.83 & 1.17 & 1.38 & -74.2 & $40: 1$ & -65.3 & -5.99 \\
\hline 7 & $\mathrm{EP}(\mathrm{EO})_{5}$ & AllylE $_{2} \mathrm{Ep}$ & 6.17 & 1.11 & 1.45 & -74.1 & $80: 1$ & -68.4 & -6.23 \\
\hline
\end{tabular}




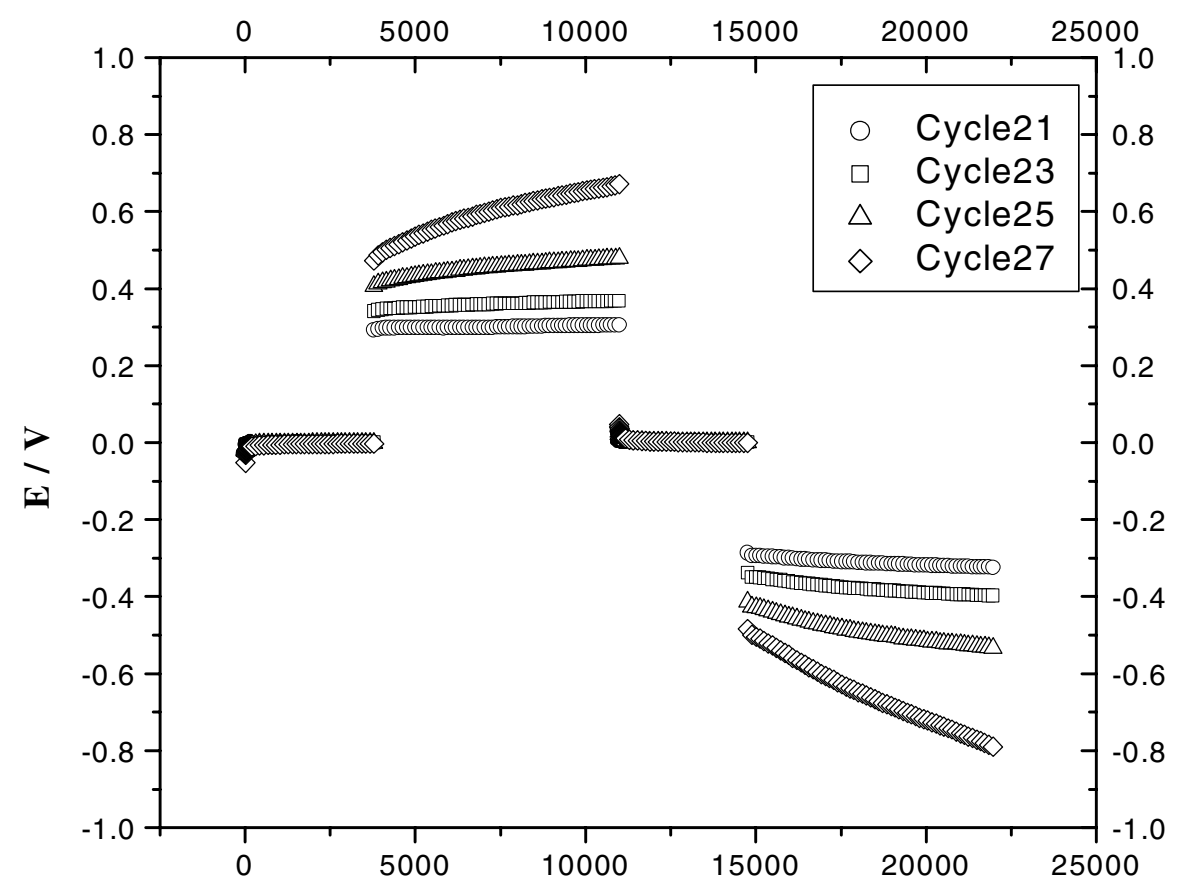

Time / s

Fig. 1. The last few cycles (after the impedance measurement at $20^{\text {th }}$ cycle) of the Li $\|$ Li cell based on the single ion conductor is $\mathrm{PEPE}_{5}$ with $\mathrm{AllylE}_{2}$ crosslinker at the salt concentration of $\mathrm{EO} / \mathrm{Li}=40$. The current density is $25 \mu \mathrm{A} \cdot \mathrm{cm}^{-2}$ and the temperature is $85^{\circ} \mathrm{C}$ 


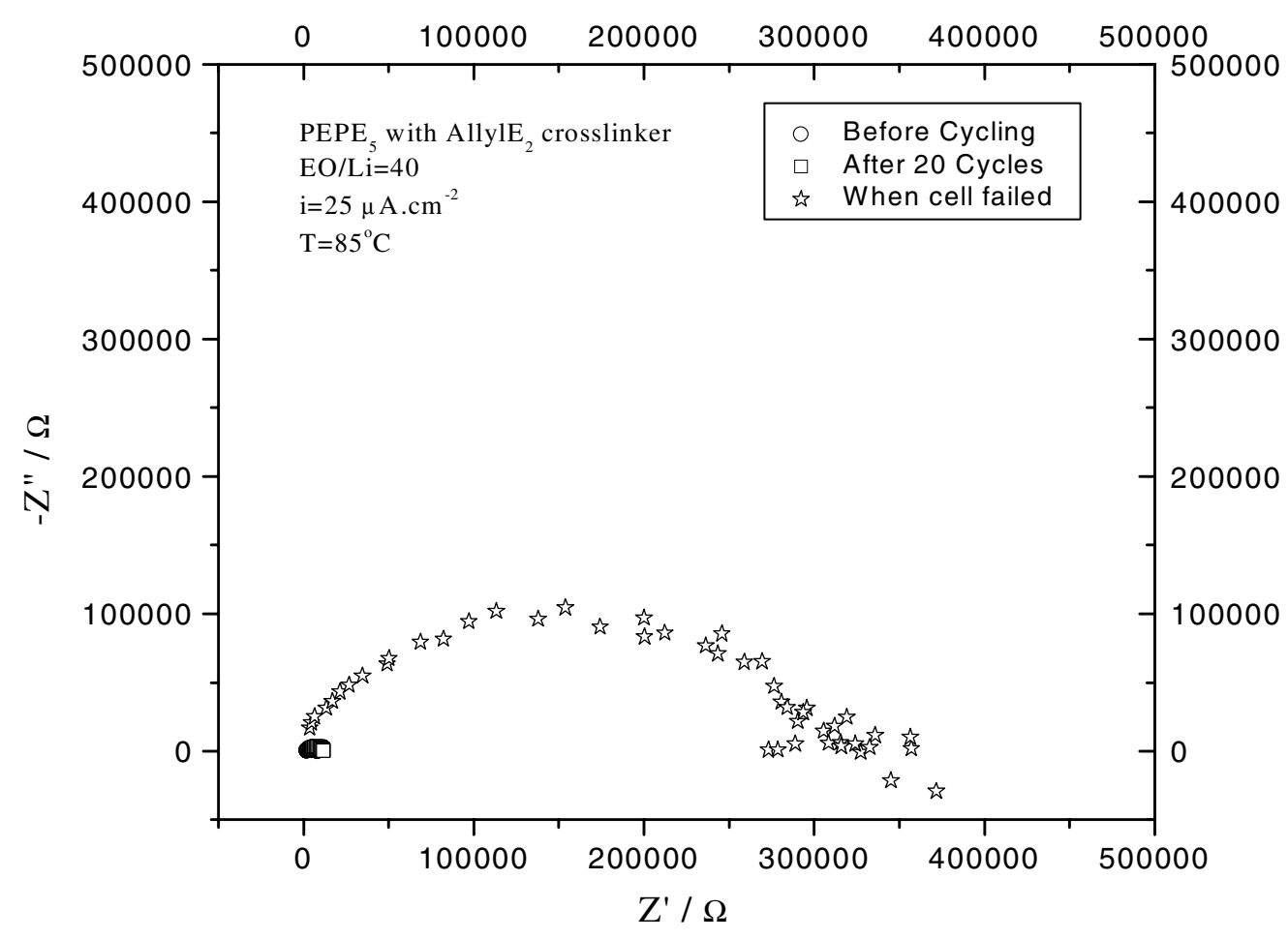

Fig. 2. The comparison of the impedance spectra (before and after cycling as well as that after

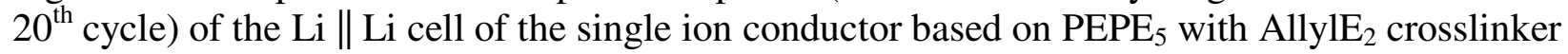
at the salt concentration of $\mathrm{EO} / \mathrm{Li}=40$. The cell was cycled at $85^{\circ} \mathrm{C}$ under the current density of $25 \mu \mathrm{A} \cdot \mathrm{cm}^{-2}$. 


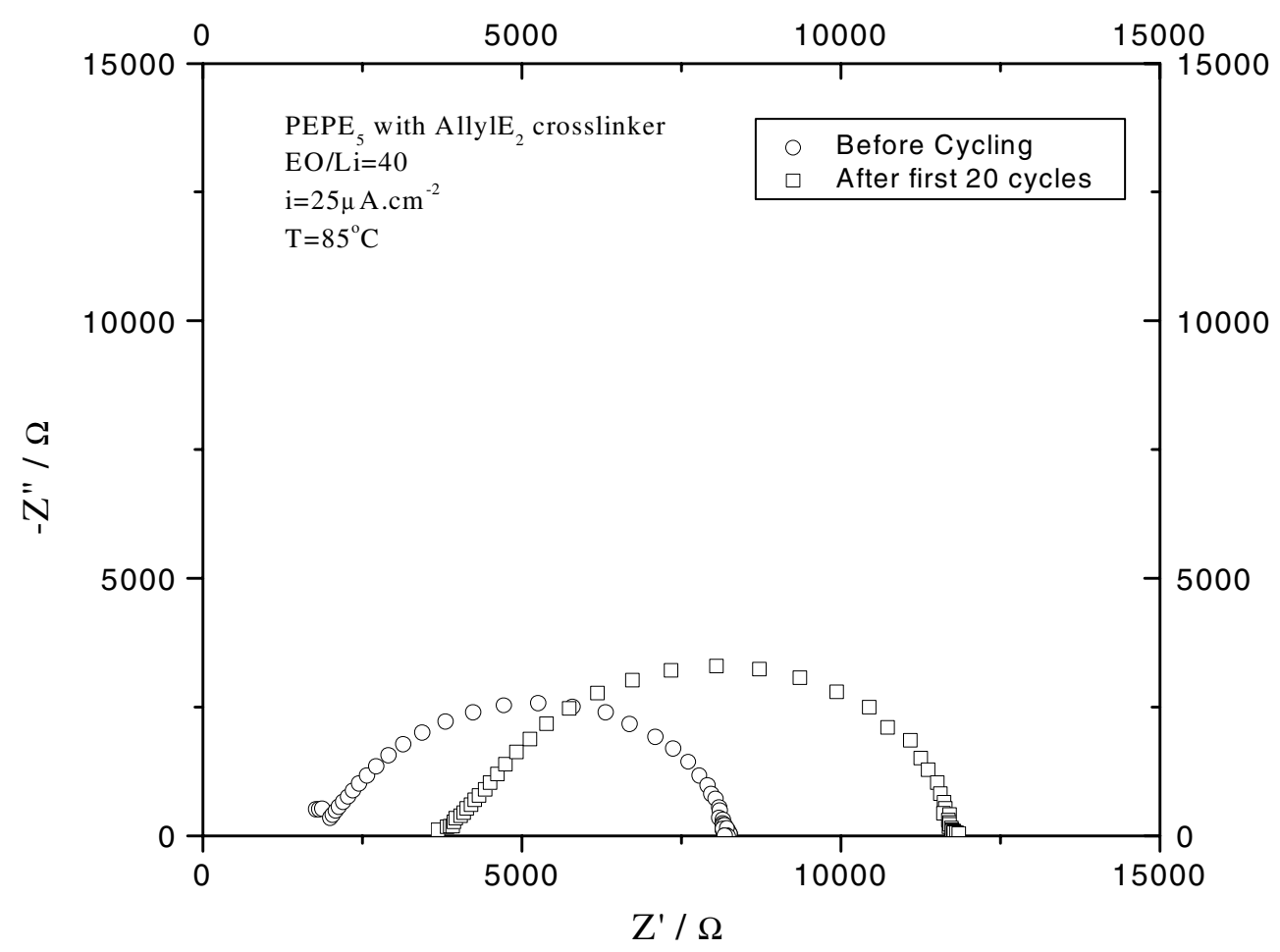

Fig. 3. The expanded comparison of the impedance spectra shown in Fig 2 for the lithium cell before cycling and after 20 cycles. 


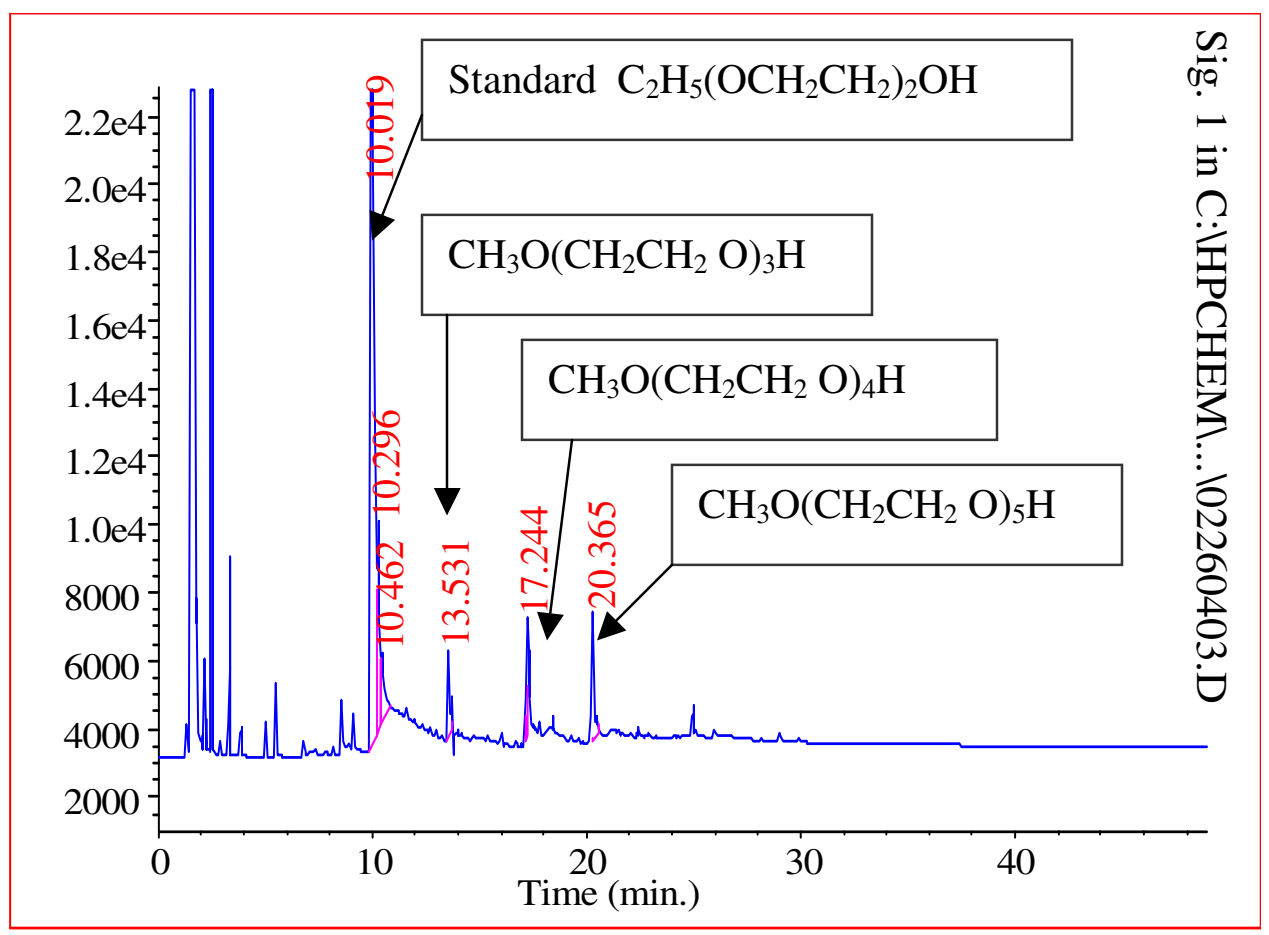

Fig. 4. GC trace of the extraction of the failed lithium cell in Fig. 1. Dichloromethane is used as solvent and Helium as gas carrier. 